\title{
The co-development of agriculture and flood-related problems in the parishes of Högsby and Mörlunda, Sweden, $1600-1800$
}

\author{
Oscar Jacobsson ${ }^{1}$ (D)
}

Received: 5 June 2019 / Accepted: 13 November 2020 / Published online: 10 December 2020

(C) The Author(s) 2020

\begin{abstract}
This paper analyses the development of flood related problems in two parishes in southeastern Sweden-Högsby and Mörlunda-during the period 1500-1800. The questions asked concern the role of the larger development of the agricultural production in the expansion of flooding problems during the late seventeenth and eighteenth centuries, and also investigates how this relationship was perceived by the local inhabitants. This is done through an analysis of the development of agriculture in the area using historical maps, combined with a study of written source material such as parish records and court protocols. The river Emån which flows through these parishes had long been a vital resource in the cattle-based economy of the studied parishes. This relationship turned more problematic by the turn of the eighteenth century due to the introduction of autumn rye into the agricultural scheme, prolonging the period of flood risk exposure for the arable crops. Combined with arable field expansion during the eighteenth century, this increased the sensitivity of agriculture to flooding. This development was not apparent in the discourse of the local inhabitants by the end of the eighteenth century, who instead interpreted increasing flooding problems in relation to existing water rights principles. These emphasized the more direct effects of human and natural obstructions in the river channel. The limits of historical memory as well as the necessities of agricultural development colored the local interpretation. Such processes on a general level were also closely inter-linked with the large-scale institutional changes of the period.
\end{abstract}

Keywords Floodplain $\cdot$ Land use $\cdot$ Flooding $\cdot$ Sweden $\cdot$ Historical geography $\cdot$ Agricultural history $\cdot$ River history $\cdot$ Emån

Oscar Jacobsson

oscar.jacobsson@humangeo.su.se

1 Department of Human Geography, Stockholm University, Svante Arrhenius väg 8, 10691 Stockholm, Sweden 


\section{Introduction}

The historical relationship between humans and flooding is a complex one. Flooding is geomorphologically and biologically a natural part of a watercourse (Charlton 2008; Mathar et al. 2015) and has produced floodplains that have been focal points of societal development for long periods of history (e.g. Tockner et al. 2008). At the same time, floods have also often caused harmful effects on societies and settlements located along rivers (e.g. Donahue 1989; Morgan 2015; Fanta et al. 2019).

This essay investigates and problematizes the development of flooding problems in agriculture during the seventeenth and eighteenth centuries in the parishes of Högsby and Mörlunda by the river Emån in southeastern Sweden. At an early stage, the inhabitants of this area used yearly spring floods as a key part of their agricultural production, and while this usage persisted throughout the eighteenth century, the relationship to flooding and the river Emån turned gradually more antagonistic. The process by which this relationship changed is an interesting object of study, as it serves as a historical background on a local level for the large drainage and reclamation projects that were conducted in Emån during the nineteenth and early twentieth centuries. (Granlund 1969; Tärnfors 1979: 30ff; Dedering 2001: $161 \mathrm{ff})$. Similar projects in Sweden have often been connected to the rise of capitalist agriculture, class conflicts and a clash between tradition and modernity (e.g. Olsson 2003; Lennqvist 2007; Runefelt 2010; Mels 2014). Regarding the interaction between human society and natural disasters such as flooding however, the social production of disasters as mediated through the intersection of culture, politics, economy and physical processes has been emphasized by international historical research (e.g. Blackbourn 2007; Mauch 2009, pp. 4-5; Morgan 2015, pp. 11-12).

The transformation of the water landscape should thus also be clearly connected to the ways in which water turns problematic within existing economic and social structures-as well as in relation to ongoing societal developments-producing the necessity of reclamation, protection measures and draining. Previous research has shown how such developments can be driven by both external demands-such as industry, transportation and trade-and local necessities such as the ecological limitations of subsistence agriculture (Donahue 1989). The river Emån was the object of a similar development, but the local transformation of agriculture seems to have initially played a more substantial role than external demands. My essay builds on themes recognized by previous research, but is also a suitable case in which local agrarian developments can be put center stage in the analysis.

Following from this, two questions are asked:

- How did large-scale changes in agriculture affect flood-related problems in the agrarian production within the studied area?

- Did contemporary inhabitants within the studied area reflect upon the problem of flooding in relation to larger economic and agrarian changes?

The first question relates to the intersection of agriculture with the production of flood-related problems and is studied through maps and written documents mainly from the seventeenth and eighteenth centuries. The second question regards the contemporary interpretation of flooding in this area-the awareness of cause/effect-and is studied mainly through court protocols from the late eighteenth century. In order to answer these questions, a "water system" perspective-as formulated by Terje Tvedt and Richard Coopey-is applied to the analysis (2010). A"water system" according to Tvedt and 
Coopey consists of three different layers: (1) physical geography:"water's physical form and behaviour", (2) human modifications:"societies' ability or determination to manipulate their water" and (3) institutions and conceptualisations:"management practices and 'habits of thoughts' or ideas about water and water control" (Tvedt and Coopey 2010, p. 7). In this paper, the second layer (human modifications) includes the agrarian economical dimension, which is an essential part of any understanding of floodplain and river control during the period. The paper is structured largely according to the layers of the water system, starting with the physical factors and ending with conceptual and institutional dimensions, but connections between the different layers emphasise their interdependency, which is an essential part of any "water system" perspective (Tvedt and Coopey 2010, p. 6).

The parishes of Högsby and Mörlunda were chosen as case studies due to the extensive character of the source material, but also due to their central location in the lower reaches of the river valley of Emån. Högsby and Mörlunda are suitable case studies in this area. I also draw on comparisons with neighboring parishes such as Målilla directly to the north. The period of study is limited to roughly 1500-1800, which enables an analysis of the processes and events leading up to discussions of drainage and river control occurring in the late eighteenth century, as well as some parts of the aftermath.

\section{Research background}

In Sweden, relatively limited research has been conducted that examines in-depth the historical relationship between human society and water, as opposed to the vibrant international field of water history (Mauch and Zeller 2008; Schönach 2017). The few notable exceptions include the work by Eva Jakobsson, which covers a broad range of water-related subjects such as the conflicting interests in the development of hydropower (Jakobsson 1996a, 2002), the Swedish history of water rights (Jakobsson 1996b, 2010) and the development of ditching activities (Jakobsson 2013). Jakobsson's research focuses on the relations between agrarian and industrial interests as well as downstream-upstream relations in water use and control. Another example includes the work of Jörgen Lennqvist on the lowering of the lakes Hjälmaren and Kvismaren in central Sweden, the actors currently and historically involved in its remaking and the environmental consequences of such modifications (Lennqvist 2007). Examples of older research include the pioneering work by Arne Fryksén on the political-agrarian and scientific discussions regarding water regulations in the eighteenth and nineteenth centuries (Fryksén 1973), and Bertil Waldén's volume on the lowering of Hjälmaren and Kvismaren (Waldén 1940). However, while environmental historians in Sweden have tended to focus on water regulations, modifications and the conflicts involved in water landscapes, few have explored floodplain problems in the agrarian production in particular.

While the general processes underlying the transformation of agriculture in Sweden have been rather extensively sketched (e.g. Wiking-Faria 2009; Gadd 2011; Myrdal 2011), water and river use has only played a rather limited role in this research in favour of other forms of land use such as arable farming (c.f. Håkansson 1997). A few exceptions exist, such as a body of work on mire reclamation (Runefelt 2008; Strandin Pers 2012), milling (e.g. Holmbäck 1914; Ek 1962; Beronius Jörpeland et al. 2013) and wet meadows (Aronsson 1979; Campbell 1982; Emanuelsson and Möller 1990; Siöstedt 1994; Bylund 1996; Strömberg 2018). However, while some studies connect the development of local water use in relation to wider economic developments (e.g. Bylund 1996), existing studies do not 
investigate the interconnections between agrarian development and human-river relations (c.f. Morgan 2015).

Thus, from a broader research perspective, the aim of this paper is mainly to fill a gap in Swedish water history as well as agrarian history, by conducting a combined empirical study in both fields. Although combined water-agrarian historical research has been conducted before (e.g. Lennqvist 2007; Jakobsson 2013)—not the least internationally (e.g. Donahue 1989; Fritzbøger 2009; Morgan 2015) - the scope has often been broad in character. By conducting a focused empirical analysis on a smaller study area, this paper hopes to contribute to the communication between agrarian and water history. This also plays into larger trends of increasing interdisciplinarity within the international discipline of river history (Schönach 2017). Both agrarian and water history in Sweden builds on developed methodological traditions, which when combined empirically may contribute to further enrichment of the field. While this paper largely leaves the call for more international, comparative and theoretical river histories unanswered (Evenden 2018), my hope is to show how detailed empirical analysis in that context still remains an essential part of understanding the development of human-river relations on the local scale.

\section{Methodology}

This paper is thus based on a combination of source materials and methods. The development of agriculture in the studied area is analysed through historical maps from 1640 to 1800 and a comparison between selected halmets in the parishes of Högsby and Mörlunda. Hamlets were selected based on the existence of seventeenth century or eighteenth century maps and through their proximity to the river Emån. The Högsby hamlets are: Huseby, Högsby, Högsholm, Bondeberga, Staby and Virstad. In Mörlunda they are: Gisslingsäng, Lundtorp, Mörlunda, Ryningsnäs and Stora Sinnerstad. Maps from these villages were georectified and the land use digitised in GIS, which enabled an analysis of the development of land use over time and a comparison with modern soil geology (Sveriges Geologiska Undersökning, SGU) and flood maps (Myndigheten för samhällsskydd och beredskap, MSB 2014).

The flood maps are based on modern hydrological conditions in Emån affected by water control and earlier drainage projects such as the lowering of the lake Ryningen in the early twentieth century (Granlund 1969). Based on this, data is given for 100-year and 200-year floods as well as Highest Calculated Flow (HCF) (MSB 2014). The 100-year and 200year floods are problematic in a historical context with different hydrological conditions, especially when comparisons with notes on historical maps state that areas only within the 200-year and HCF zone experience sporadical flooding. ${ }^{1}$ In this paper, the HCF data is thus used to define the maximum floodplain of the river Emån with a greater historical depth, but is also compared and verified through the use of written source material (see below). Nonetheless, the quantitative parts of the historical land-use analysis below should be viewed with this in mind.

The history of flooding and flood-related problems in the area were analysed through a combination of different source material. Late eighteenth century court records from the

\footnotetext{
1 This indicates that floods of such magnitude were more frequent in the period studied in this paper. Examples of this can be seen in the historical maps LSA g4:90-91 (1646), LSA G70-18:1 (1692), LMA 08-hby-7 (1706) \& LSA G70-39:1 (1696).
} 
härader ${ }^{2}$ of Handbörd (in which Högsby is situatied) and neighboring Aspeland (with Mörlunda) are used to analyse the arguments for increased draining of the river, as well as the local perception of the causes of flood-related problems. The problems themselves were mainly studied through parish records in Church archives, which contains notes on "spectacular events" written down by the parish priest. Such notes, found on a regular basis from the late seventeenth centuries and onwards, often describe weather events that affected the inhabitants of the area (Ingesson 2017). ${ }^{3}$ A few notes from neighboring parishes also exist from the late sixteenth and early seventeenth centuries.

Inhabitants of the area often connected increasing flood-related problems to the damming of the river through both natural obstacles (e.g. trees, rocks or debris) and human constructions (e.g. dams and weirs) and thus the logic behind this reasoning can be scrutinized. In this paper, this is done through an analysis of the development of milling activities in the main channel in the parish of Högsby, using a survey of historical maps in combination with primary and published written source material. ${ }^{4}$

The notes in the church archives can also be used to study variations in weather over time, in a more quantitative manner, to see if increased flood-related problems were connected to an actual increase in flood recurrence. For this study, variations in droughts and floods have been studied through these notes in a manner similar to the methodology used by Dag Retsö on a national level (Retsö 2015).

\section{The physical setting}

As every waterway is to a certain extent unique in its physical characteristics, it is first important to outline the structure of the physical landscape of Emån in accordance with the water system perspective. These characteristics were important foundations for the development of land use in this area, and to a certain extent explain some of the problems that developed in relation to flooding.

The river Emån is approximately $220 \mathrm{~km}$ long and its watershed covers an area of $4500 \mathrm{~km}^{2}$. This waterway drains parts of the South-Swedish highlands and starts at an elevation of $330 \mathrm{~m}$ above sea level (see Fig. 1). Being a part of eastern Småland, the climate of this region is generally relatively dry, with most precipitation during summer and winter (Andréasson and Carlsson 1973, p. 9).

Having travelled through narrow passages in a landscape mostly dominated by glacial till, the river valley near Målilla (just north of Mörlunda) opens onto a wide and flat plain dominated by glaciofluvial and postglacial sand. The floodplain covers most of this valley, which still today experiences rather frequent flooding. When the river reaches Mörlunda, the stretches of land closest to the river (levees) are dominated by sandy soils, while more low-lying areas beyond are mixed with silt and finer sediments. On the southern parts of

\footnotetext{
2 A"härad" is an administrative and historically mainly judicial regional unit which at least roughly corresponds to the English term "hundred".

3 These notes are often found in the margins of the statistical forms from the period after 1749 (see the series GIII, Redogörelser för folkmängden, statistiska tabeller in the church archives) and for the period from 1680-1800 often in a series called Historiska anteckningar (not seldom contained in series C1, Födelse- och Dopböcker).

4 The primary source material consists of the Mill Commission from 1697 (Kvarnkommissionen) as well as relevant court records from the eighteenth century. Earlier periods were analysed by the use of the published material survey in Det Medeltida Sverige (Brunius and Ferm 1990, Axelsson and Rahmqvist 1999).
} 


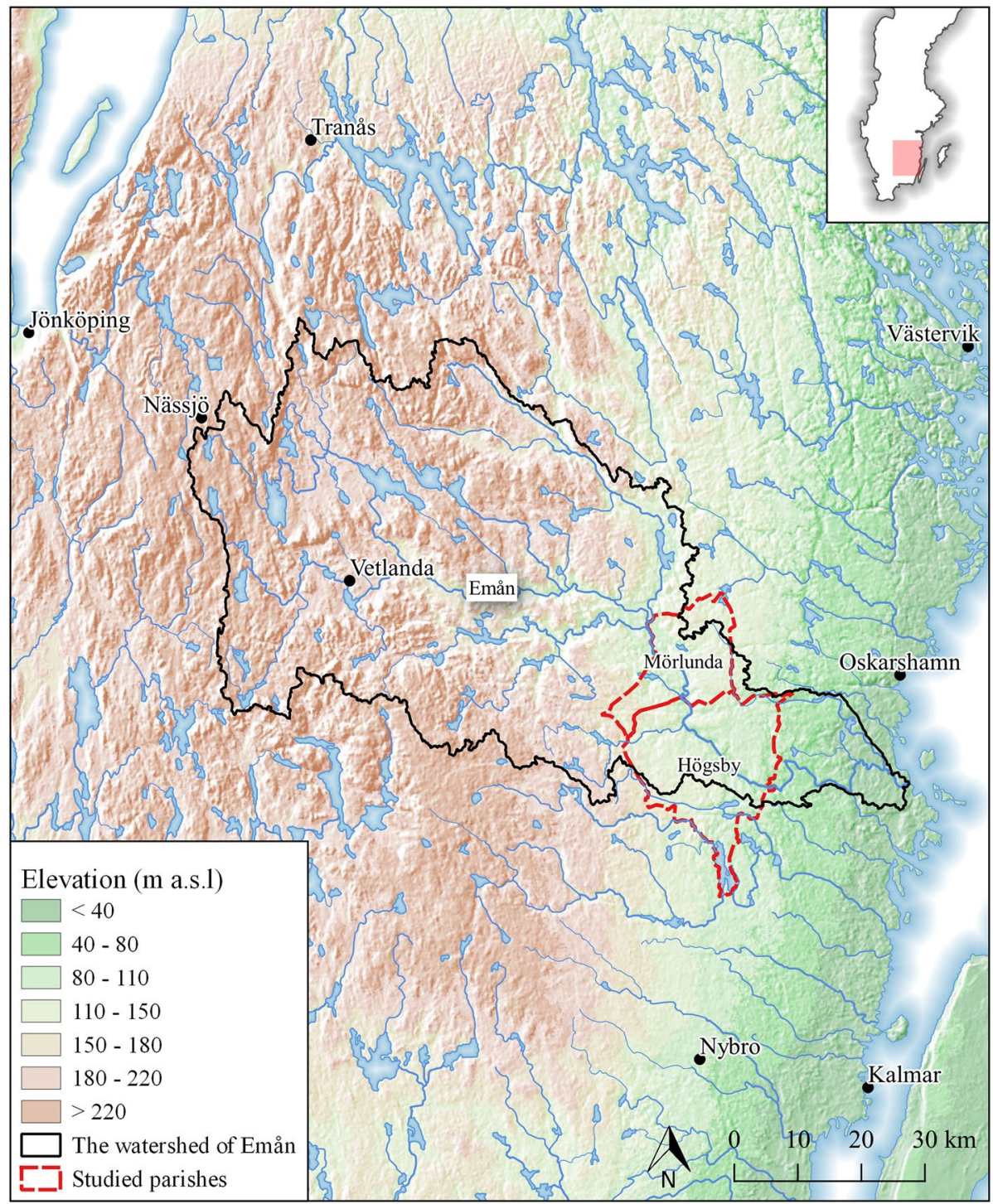

(c) Lantmäteriet \& SMHI

Fig. 1 Map showing the watershed of Emån and the location of the studied parishes

this plain, the river has formed natural levees from coarser material, raising the riverbed above the surrounding floodplain. Farther downstream, after rapids and falls of about $4 \mathrm{~m}$, the river Emån reaches the now-lowered Lake Ryningen, which at the present consists mostly of wet pastures that are sometimes flooded in spring. South of Ryningen the river enters the parish of Högsby. Here, the low-lying silt surrounding the river becomes more intermixed with clay soils.

While the floodplain has been largely cultivated and the river regulated during the late nineteenth and early twentieth century, there is no evidence that these modern projects have 
affected the soil geology or the topography of the floodplain in any significant manner, as is common in the post-reclamation phase of lakes and wetlands (e.g. Tuvesson 2010). The organic soils that usually subside after such projects are not commonly extensive or thick in similar floodplain contexts in Scandinavia, especially not on the raised, well-drained levees along watercourses (L-O Westerberg dept. of physical geography, Stockholm University 2020, personal communication, 11 February). Historical geologic maps (SGU Ab Hvetlanda III.Ö.37, 1883) and a hydrological study of the river from the late nineteenth century also largely show consistency with modern conditions (Wedblad 1894).

In Högsby, the flow of Emån has a quite distinct seasonal variability, which can be visualized through measurements conducted at the station of Blankaström from 1928 and onwards (SMHI Vattenweb). The monthly mean flow between 1928 and 1945 (within the study period of this paper) suggests a pattern with high winter and spring flows peaking in April (mostly due to snow melting), with the period from July to October being characterized by much lower flows. Taking the whole period from 1928 to 2017 into account, the mean flows increase for almost every month but the general seasonal pattern is strengthened. While the spring floods are usually extended over several weeks, high precipitation in summer leading to short and intensive floods is not entirely uncommon (Andréasson and Carlsson 1973, pp. 11-12).

\section{The agricultural system and floodplain land use in Högsby and Mörlunda during the sixteenth and seventeenth centuries}

First, it is necessary to sketch the backdrop upon which the transformations of the late seventeenth and eighteenth centuries were played out. The land use of the preceding periods was most likely part of a longer medieval tradition in which the agricultural system was based on a diverse yet still specialised production where environmental problems were handled internally. The characteristics of this land use system and the historical patterns in which it emerged are outlined below.

The river Emån has been a highly active part of the agricultural system of Högsby and Mörlunda since at least the Middle Ages, which is highlighted by the fact that most of the settlements from the thirteenth to fifteenth centuries were situated in the river valley (Brunius and Ferm 1990; Axelsson and Rahmqvist 1999). From the late Middle Ages and into the nineteenth century, the floodplain of Emån was used as hay producing meadowlands. These meadows benefited from the yearly flooding of the river, which left behind nutrients and provided a form of natural fertilization which enhanced the growth of the grass (Granlund 1969; Aronsson 1979; Dedering 2001, p. 147). The importance of such meadows for the agrarian production of the area can be seen in several large meadows by the river owned by several and sometimes distant farms (e.g. LSA G41-51:2 1720), in which cooperation between several settlement units was necessary for activities such as ditching and the building of fences. Each settlement unit in the river valley also had its own meadows that were managed in a similar manner.

During the period up until the late seventeenth century, the agrarian system was dominated by annual cropping, which meant that a large amount of manure was needed to fertilize the arable fields and render the system sustainable. This agrarian system in turn was based on cattle breeding rather than seed cultivation, and the floodplain meadows (which constituted a clear majority of all meadowlands in the area) played a highly important role. In turn, the prominent status of cattle breeding in this area can be at least partly attributed 


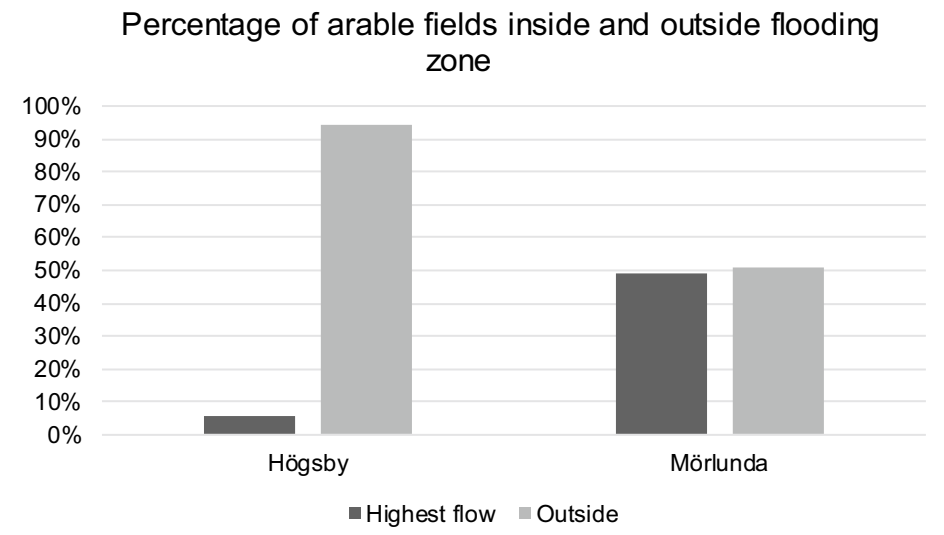

Fig. 2 Column chart showing the percentage of total arable fields within and outside the flooding zone (HCF) in Högsby (period 1680-1726) and Mörlunda (period 1692-1725). This analysis was done through digitalization of arable fields on historical maps in GIS for the six settlement units Huseby, Högsby, Högsholm, Bondeberga, Staby and Virstad, covering the time period between 1680 and 1726. The data was then combined with flood maps from MSB (100-year flow and Highest flow). In Mörlunda, a similar analysis was conducted on the five settlement units of Gisslingsäng, Lundtorp, Mörlunda, Ryningsnäs and Stora Sinnerstad covering the period between 1692 and 1725

to long-distance trade with oxen. In the 1600 s, oxen from the county of Kalmar were primarily exported to Stockholm and the mining areas of Bergslagen (Lagerstedt 1953; Myrdal 2011: 109-110). The härader of Handbörd, Aspeland and Sevede, where Högsy and Mörlunda were located, were some of the first areas involved in this trade and as a result enjoyed relative prosperity during the sixteenth century (Höglin 2001, p. 25).

In the annual cropping system, the usual spring sown crops were exposed to flooding threats from sowing in April till the harvest in September, but the main crop of barley was usually sown after the common flooding period in May. It was only spring-rye that was sown in April (Craelius 1986, p. 183), and at least during the sixteenth century, spring-rye was commonly sown in the outlands through slash-and-burn techniques (Vestbö-Franzén 2004, 2005). For the meadows, especially wet conditions during the mowing period in July was a substantial problem (LSA G41-46:1 1695, LMA 08-hby-7 1706), although in the climatic context of the area this was rather unusual (see above).

Most of the larger hamlets in Högsby parish were located in the river valley of Emån and the arable fields were often situated on slopes or areas with higher elevation surrounding the floodplain. During the turn of the eighteenth century (which is when detailed historical maps of this area first start to appear), the arable fields were thus generally situated outside the long-term floodplain boundary, and lay protected from floods that could ruin harvests or complicate activities connected to arable cultivation (Fig. 2). This may have been the result of specific farming knowledge concerning flooding risks in the area, but more likely this relationship was caused by the importance of the floodplain for hay production. The limited amount of arable land on the floodplain during this period is almost always described as "periodically suffering from floods". 5

${ }_{5}$ Maps with such notes are e.g. LSA g4:90-91 1646, LMA 08-hby-7 1706. 


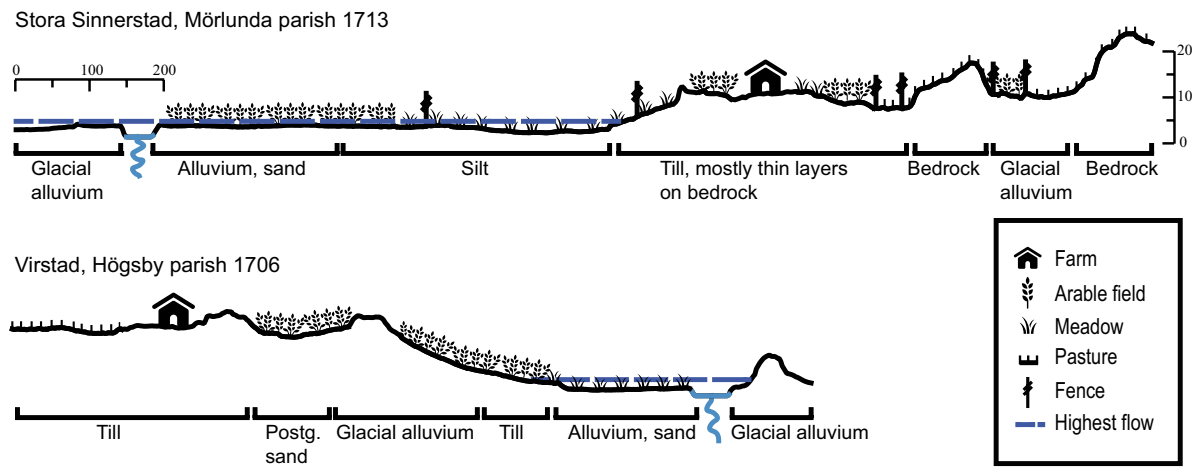

Fig. 3 Landscape profiles of Stora Sinnerstad (Mörlunda) and Virstad (Högsby) showing some of the major differences in land use localization between the two parishes, in relation to topography, flooding zones and soil geology

A comparison with the neighbouring parish of Mörlunda illuminates some interesting differences. In Mörlunda during the same period, a considerably larger amount of arable land was situated within the long-term floodplain boundary (Fig. 2). ${ }^{6}$ This was likely the result of three different factors. Firstly, the extensive floodplain made opportunities for settlement and cultivation outside the flooding boundaries highly limited. Secondly, the arable fields within the flooding boundary was to a large degree located on natural levees with coarser sediment soils (such as sand), which would drain more quickly than finer sediments such as clay and silt (see Fig. 3). Thirdly, the field location may have been an active choice in an area where summer droughts constituted a threat to the cultivation. The glaciofluvial and alluvial sediments of the floodplain had larger groundwater reserves, which may have reduced potential harvest losses caused by droughts. The fields closest to the river in Mörlunda during the turn of the eighteenth century show no signs of being recently cultivated in the context of changing field systems (see below) and are most likely older fields which existed at least during the late sixteenth century when parish records of flooding from the neighbouring area start to appear.

During the period up until the end of the seventeenth century, the archival material concerning flood-related problems is scarce, and non-existing concerning spring floods. For the parish of Målilla, situated by Emån just north of Mörlunda, a few notes exist concerning pluvial floods from the years $1585-1610 .^{7}$ In 1588 for example, heavy rainfall in July caused a flood that swept away the new-mown grass and, in many areas, extended onto the arable fields; cattle died and people went hungry. ${ }^{8} 1597$ was an equally disastrous year. On the 12th of May a torrent of rain came that swept away the newly sown seeds and flooded the fields, after which the water froze. The 17th of June brought a new pluvial flood that swept away the sown seeds, which presumably were just re-sown after the earlier event. This year families had to make bread out of bark and roots. While no such records for this

\footnotetext{
6 The arable fields connected to the main floodplain on historical maps from seventeenth century is noted as flood prone, see e.g. LSA G70-18:1 1692, LSA G70-30:1 1696, LSA G70-39:1 1696.

7 Målilla kyrkoarkiv, C:1-3. Födelse- och dopböcker. Landsarkivet i Vadstena.

${ }^{8}$ It is uncertain but most likely that cattle died of starvation (or were slaughtered?) due to the lack of fodder resulting from the flood, rather than directly in the flood itself. See Volume C1, page 220, Målilla church archive.
} 
period exist for the parishes of Högsby and Mörlunda, later records from the end of the seventeenth century and the eighteenth century display a similar picture. ${ }^{9}$ Målilla—displaying many land use similarities to Mörlunda-should have been more exposed to diverse problems relating to the flooding of arable fields and meadow than Högsby, where the arable fields within the flooding zone were highly limited. In records from the eighteenth century, flood-related problems in Mörlunda and Målilla are described in more dramatic terms with more severe consequences than in Högsby. For example, human and cattle casualties are not mentioned in records from Högsby, but are mentioned in Mörlunda (1694, 1695 and 1745) and Målilla (1586 and 1745). ${ }^{10}$

It is thus clear that even during the sixteenth and seventeenth centuries the problems of flooding were real and sometimes substantial in the studied parishes. Floods caused by excessive rainfall were a particular problem, which is reasonable when the main in-field crop barley could be sown after the spring flood period ended in May. The strategy for handling environmental problems such as floods and droughts during this period was probably tied to a diversification of land use and crops, not the least geographically. Where wet years would affect the crops and meadows within the flooding zone, these areas could better handle complications brought by summer droughts, which could have drastic consequences for both rye and barley. By spreading crops and land uses along the landscape profile (see Fig. 3) these hydrological complications could be limited.

\section{Crop transitions and arable fields expansion, seventeenth to early eighteenth centuries}

During the latter half of the seventeenth century and into the eighteenth century several transformations occurred in the studied parishes that led to increasing flood-related problems. Spring floods now started to be more problematic in relation to the production of grains on arable fields. While the transformations themselves where mostly connected to larger processes, the way in which they were manifested locally had more widespread consequences for human-river relations. The characteristics of these transformations are described in this section.

During the period of roughly 1690-1750, several villages especially in the river valley of Emån turned from the earlier one field system with annual cropping to a three-field system, where one field lay fallow each year and a particular rotation of crops was practiced (Granlund 1969). The introduction of the three-field system in this region has been tied to the cultivation of autumn rye on the infields following increased outland colonisation, and also the generally increasing importance of rye in farmer consumption (Vestbö-Franzén 2004). This process can be observed in large parts of the county of Kalmar (Vestbö-Franzén 2005), and is connected to similar developments occurring earlier in parts of the neighbouring county of Jönköping to the west (Vestbö-Franzén 2004).

The historian Lennart Andersson Palm has shown how the seed-yield ratio of autumn rye in different regions of Sweden was an important factor behind its geographical range. A wet winter or spring affected the autumn rye negatively, and it was thus especially suitable in the eastern Swedish climate with colder winters and generally drier conditions. In these

\footnotetext{
9 Högsby kyrkoarkiv, KI:1-2 \& GIII; Mörlunda kyrkoarkiv, C:1, GIII.

10 See Högsby kyrkoarkiv, KI:1-2; Mörlunda kyrkoarkiv, C:1; Målilla kyrkoarkiv C:1.
} 
areas, autumn rye gave higher yields than spring rye and was therefore a rational choice (Palm 2005).

In the floodplain context of Högsby and Mörlunda however, the introduction of autumn rye also led to increased risks. Autumn rye in Högsby was sown in late August/September and harvested in early August next year (Craelius 1986, p. 183), and its most sensitive period also corresponds to the period with the highest flow in the river Emån. Despite this, autumn rye was apparently cultivated in floodplain contexts. In parish records from the eighteenth century-both from Högsby (1785) Mörlunda (1695, 1703, 1751, 1770, $1785,1788)$ and Målilla $(1785,1789)$ - problems with autumn rye due to spring floods are directly mentioned. ${ }^{11}$ The introduction of autumn rye in this area introduced a prolonged period of flood risk exposure for the arable crops, where spring floods, whose harmful effects had previously been more avoidable, started to affect agriculture negatively. Especially in Mörlunda, where a substantial part of the arable fields were located on natural levees of the long-term floodplain, this development must have presented particular challenges.

It has also been suggested that the transition to the three-field system led to an expansion of arable fields (Vestbö-Franzén 2004, p. 111), which could have increased the flood risk exposure. The expansion of arable fields that occurred in this period seems however unrelated to changing field-systems. Both settlements practicing a three-field system and others with annual cropping show signs of recent land clearance around the turn of the eighteenth century. ${ }^{12}$ There is also very limited evidence that this expansion occurred on the floodplain. Instead, a more likely explanation can be found in the rising population. According to Lennart Andersson Palm the population in both Mörlunda and Högsby grew by $122 \%$ and $132 \%$ between 1620 and 1699 (Palm 2000). This quite substantial population growth should have been accompanied by a need for a more extensive food supply. ${ }^{13}$

The expansion of arable fields continued during the entire eighteenth century. In Högsby, the arable fields in the six studied hamlets (see note 3 ) grew by $72 \%$ between the start and end of the eighteenth century. Most of this expansion occurred on drier parts of the infield meadows and through clearing away obstacles in already existing fields. However, a limited expansion also occurred within the long-term floodplain boundary. In Mörlunda, this process is more difficult to trace due to a discontinuity in the historical maps of the studied units during this period. However, studies of the settlement units of Stora Sinnerstad, Mörlunda, Gisslingsäng reveal a more limited—although existing — arable fields expansion on both dry land and floodplain when compared to Högsby (for an example see Fig. 4). This expansion was most likely driven by a combination of demographic changes, technological development and changing class and land ownership structures. The technological changes included the increasing use of the scythe for harvests in the region (Craelius 1986, pp. 185-86). Between the years 1699 and 1805 the population in Mörlunda and Högsby once again grew substantially by $132 \%$ and 133\% (Palm 2000). Both Högsby and

\footnotetext{
11 In records from Högsby problems due to excessive rain are mentioned two further years-1789 and 1800 - although it is unclear whether this is directly related to floods. Högsby kyrkoarkiv, GIII.

12 Arable field expansion in settlements with recently changed field systems are e.g. LMA 08-hby-7 1706, LSA G19-10:1 1724, LSA G41-51:2 1771. Expanding arable in settlements with annual cropping can be seen in LSA G41-44:1 1705, LSA G41-7:2 1706.

13 It should be noted that Palm's population calculations for the pre-census period (before 1750) has been criticized for underestimating population and mortality rates for the seventeenth century, thus resulting in a very large population rise during the course of the century (Edvinsson 2015). Andersson Palm has responded to this criticism (Palm 2016) and the debate seems to be still ongoing.
} 

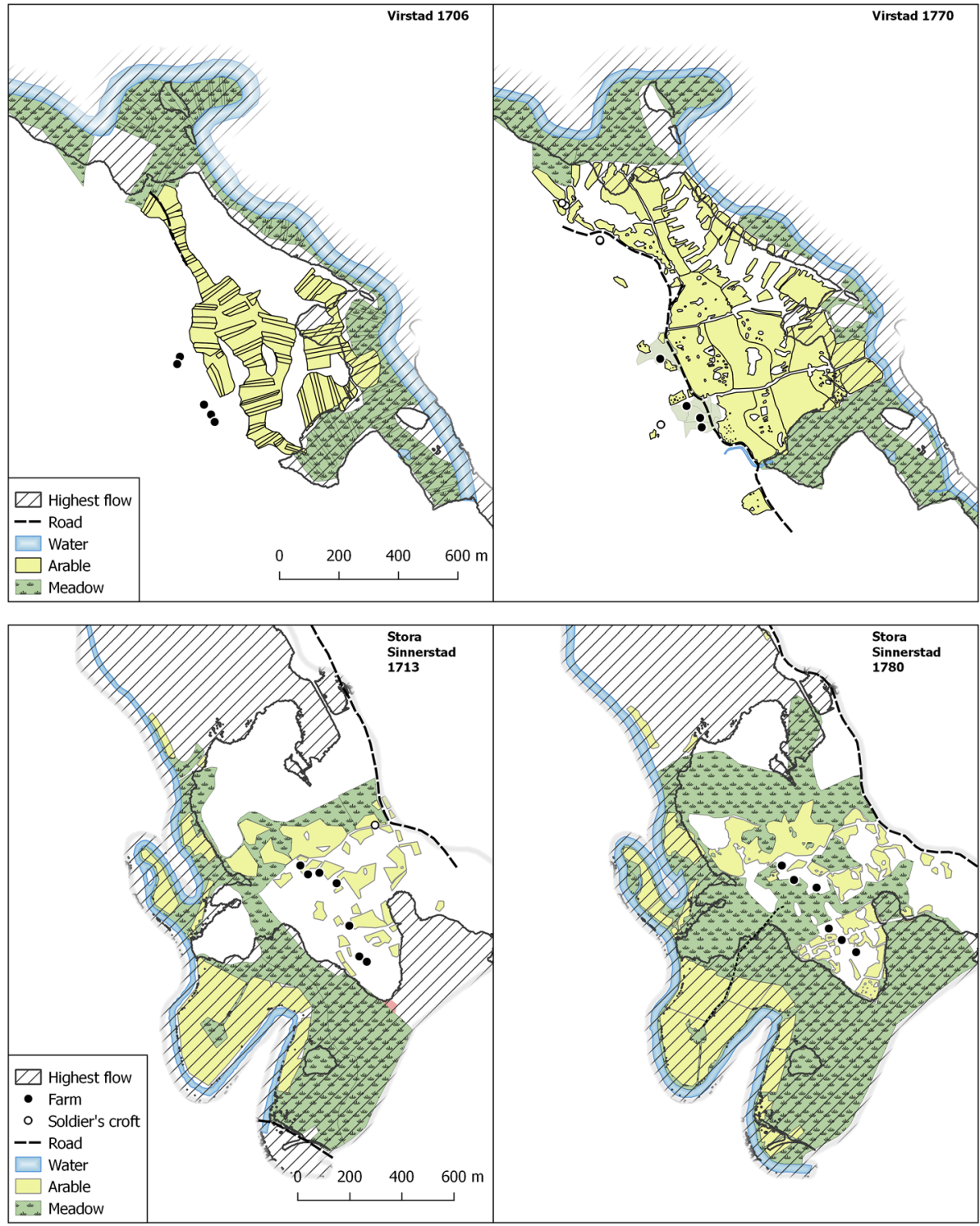

Fig. 4 Above: Two maps of the hamlet of Virstad showing the transition between a one-field and a threefield system. This is one of the few (perhaps only?) locations where such a transition can be observed directly in historical maps. Below: Two maps of the village of Stora Sinnerstad during the same period, although without any field system transition. The maps also show the highest flow of Emån as calculated by MSB (MSB 2014)

Mörlunda experienced a growth of freeholders during this period, but the nobility was a stronger landholder in Högsby by the turn of the nineteenth century than Mörlunda, where freeholders held a majority of the tax units (mantal) (Palm 2014). The growth of the freeholder class, mostly on former church and royal estate land that had been sold, is mirrored in the rest of Sweden during the eighteenth century (Gadd 2011, p. 136). In combination 
with the enclosure act, called storskifte, which served to partly concentrate previously dispersedly owned land on the infields, the development of free-holding land ownership could have served to facilitate incentives for arable field expansion.

In summary, there were two important parallel on-going processes that gradually increased the flood risk exposure of agriculture in the parishes of Högsby and Mörlunda. The transition into three-course rotation with autumn rye should be seen as the key reason why spring floods start to be more problematic by the end of the seventeenth century. The expansion of arable fields, though limited in floodplain contexts, nonetheless led to an expanding geographical area within the floodplain that was sensitive to flooding, and the transition into autumn rye cultivation within a three-field system increased the temporal exposure to flood-related problems. Population increase in both parishes would have increased the pressure on the natural resources within the parishes, most likely leading to an increasing inflexibility in terms of the primary and secondary resources which could be mobilised to alleviate agricultural crises. Although to a certain extent expansion of arable fields as well as outland colonisation increased the carrying capacity of the area, for the farmers of the river valley this meant that they increasingly came to rely on resources produced within the boundary of the floodplain. The more general transformations of agriculture tied to the larger processes of the agricultural revolution may have also served as important driving forces for the development that followed.

\section{Courts raise the issue of flooding in the late eighteenth century}

In 1772, the regional court in the neighbouring härad of Aspeland raised the question of problematic flooding (Aspelands häradsrätt 1772), where both arable fields and meadows were claimed to have suffered from damage caused by particularly severe spring floods. Questions were raised concerning the causes of this flooding, and in 1778 a surveyor named Jonas Collin mapped the river Emån from the parish of Målilla (in Aspeland) to the Baltic Sea (LSA G65-1:1 1778). The purpose was to assess if human-made constructions obstructed the free flow of the river, and to what extent the natural conditions could be improved to provide better drainage. Obstacles in Högsby parish that became the object of much discussion in the map description were particularly mill dams on the lands of the village Drageryd in the river's tributaries by the Häcklaberget hill in the northern of part of the parish and fishing weirs upstream from the falls at Hanåsa.

Collin's map and its results became the object of debates in a series of court proceedings, particularly during the summer of 1787 (Handbörds häradsrätt 1787). Farmers and local noblemen were seemingly more or less willing to change the locations, structures or layout of water mills and weirs, as the two weirs at Hanåsa mentioned on Collin's map were by this time removed and the mills at one tributary by Häcklaberget had been moved further downstream. Much more concern was raised regarding changes to the natural conditions, where an outcrop of Häcklaberget on the border between the parishes of Mörlunda and Högsby was particularly considered an obstacle preventing the draining of land upstream-particularly the lake of Ryningen but also the plains of Mörlunda and Mållilla further upstream. The court found little evidence for the effect of milling and damming activites on the flooding of the river, although the verdict stated that drainage actions were required at Häcklaberget, first regarding two abandoned mill dams and later its natural form. The inhabitants of Högsby protested however against using explosives to widen the river channel passing by the hill top, as they were concerned that the water thus released 
would cause damage to their lands downstream (Granlund 1969, p. 218ff). The farmers also claimed that Captain Baumgarten of Ryningsnäs in the parish of Mörlunda was active in this enterprise for his own gain. They thought he sought to lower the water levels of Lake Ryningen and extend his meadowlands and that the captain and his own men should conduct the massive work required to clear the river, since a majority of necessary locations were located in Högsby parish (Högsby kyrkoarkiv KIa:2). The cases raised in the regional courts did not lead to any extensive draining enterprises during this period, not the least because the county government of Kalmar-in relation to the concerns of the Högsby farmers-banned the further use of explosives in the river channel near Häcklaberget (Granlund 1969, p. 219). It was not until the end of the nineteenth century that any larger regulation of the river and draining of its floodplain took place. Lake Ryningen was first extensively lowered through the use of explosives in 1917 (Granlund 1969: 220).

One of the main concerns for the inhabitants in the härader of Aspeland and Handbörd in the above-mentioned development was the impression that flooding had become more common than in the past (e.g. Handbörds häradsrätt 1787: 736). The problem with mill dams and constructed obstacles in combination with the damming effect of Häcklaberget seems to have been the main object of discussion and was often invoked as the cause for problematic flooding throughout most of the eighteenth century. There were nonetheless also some uncertainties regarding to what degree mill dams at certain locations could cause altered river flows. The discussion and its different focuses are revealed through the investigations and arguments contained in the court protocol concerning mill dams and connected problems, here exemplified by the following passages:

The chief constable, with the other parish men and representatives of Mörlunda, claims that the mill of Drageryd-although its relocation to some extent increased the water's flow-nevertheless still is a noticeable obstacle to its free flow during incident flooding. Especially as the abundance of water before 1730 was more rare than later, when this and the already abandoned flour mill were established, and consequently follows that the same mills cause noticeable damming; Then it is alleged that Drageryd's sawmill, as also not recorded in the mill commission protocol of 1698 , must not only be completely destroyed but also, that this as well as the second stream to all parts be cleared and, in addition, blasting in Häcklaberget ... must be allowed (author's translation, Handbörds Häradsrätt 1787:732, 749).

The witness is unfamiliar with as to whether the water has come stronger since the waterworks at Häcklaberget were moved, but the flood waters must have been as abundant before as later; the witness is equally unknowing if the stream has been filled for one reason or another. ... And, according to the witness's statement, the mills of Berga (Frövi and Hanåsa) cannot cause any harm through damming on neighboring lands; for the witness has his meadow beside the stream above Torpeström, and as soon as the water comes, it drains; As for the other farms upstream, the witness is of the same opinion (author's translation, witness testimony from Jöns Peterson, 74 years old and former farmer from Yttre Valåkra (Högsby), Handbörds häradsrätt 1787: 796-97).

It seems clear from the court protocol that the people of the area-both nobles and commoners - were fully aware that human constructions could alter the flow of water with negative consequences. The discussion did not concern this fundamental view, but rather the direct effects of specific alterations to the flow of water and especially the structure of the natural landscape. 
The awareness of the problems involved in human alterations to water flow must be viewed in light of the principles of Swedish water rights. Swedish water rights are based on the concept of riparianism, which means that someone who owns the shores of a lake or river also has the right to use the water connected to that shore. Connected to this is also the principle of natural flow, which means that the natural flow of water should not be altered (Jakobsson 2010, pp. 428-29). Riparianism and the principle of natural flow had been active parts of the legal system since the middle ages, stating that a landowner did not have the right to build mills and dams that would harm the property of another land owner. Furthermore, the legal institution kungsådra (king's vein in English), which is first mentioned in a court record from 1442, limited the riparian rights as a certain part of a waterway (called kungsådra) should be kept open and unaltered (Jakobsson 1996b, p. 85). Although the origin and purpose of the kungsådra remains rather unclear, it certainly played into the principle of natural flow. According to Eva Jakobsson however, the preeighteenth century "function of the king's vein was to protect migrating fish, guard against flooding and preserve navigable passages (Jakobsson 2010, p. 429)." A discussion regarding a potential kungsådra in Emån appeared in the $1620 \mathrm{~s}$ (Westman 1920, pp. 81-82), and is also clearly described in one place close to the river mouth on a map from 1645 (LSA G1). It is however unknown if this early kungsådra continued into the parishes studied here.

In 1734 and 1766 this law and the waterways that were affected by it were more fully defined and came to affect for more rivers than previously. In the late eighteenth century, a kungsådra existed in the river Emån in both Mörlunda and Högsby, and was involved in the court cases. Furthermore, an important decree was also issued in 1764 stating that natural conditions could be in conflict with the principle of natural flow. This meant that the "natural" state of a river could be changed to more fully serve this principle (Jakobsson 1996b, pp. 90-91). The natural form of Häcklaberget in this context could therefore be seen as in violation with the law. Furthermore, the general principles of Swedish water rights explain to a certain extent the awareness of the people of the studied parishes of the effect of their alterations on the flow of water.

In 1787, the court mainly shifted the focus of the flooding debate from mills to the natural form of Häcklaberget and the need for dredging actions in river channel and streams. Studies of the archival evidence also seem to support the limited role of mills in the Emån in the flooding problems of the eighteenth century, revealing a general decrease-and maybe a concentration — of milling activities in the main channel. ${ }^{14}$ Actions were also taken prior to the court case at all the critical locations noted on Collin's map in the studied area (LSA G65-1:1 1778), and the flooding apparently continued to cause problems. Instead, there was a sentiment—not the least in the higher circles of the local society-that the river had silted up due to human alterations and lack of management, but also that the general natural landscape was unfavourably constructed and in need of improvement. Captain Baumgarten and representatives from the parishes of Mörlunda and Tveta write in an attachment to the court protocol of 1787 :

As far as Häcklaberget is concerned, this hill top cannot be held in such sanctity only because Nature gave it the miserable and harmful shape that it now has, as if

\footnotetext{
14 The milling history of the main channel from the Middle Ages and onwards can be roughly studied through a combination of source materials: medieval letters (e.g. SDHK 4998, 6858, 6264), historical maps (e.g. LMA 08-hby-371, LSA G65-1:1), the Royal Mill Commission (Kammarkollegiet 1697-1700) and court protocols (Handbörds häradsrätt 1787).
} 
it's not quite a hindrance to the water's drainage and through whose damming many thousands of barrels of grain for us have been ruined, can undergo change and blasting, especially as the inhabitants of some thirty farms, of a few hundred, and perhaps thousands of people, thereby be saved from destruction (author's translation, Handbörds Häradsrätt 1787: 738).

The view put forward in the quote above seems to be affected by the decree issued in 1764 . Where dams or weirs had previously been the objects of discussion concerning the principle of natural flow, now in focus was a natural feature.

As observed in the material from the courts, there is no critical reflection on recent land use developments in the local discourse. However, the results from the analysis of agricultural development outlined above indicate that the sensitivity to floods increased during the late seventeenth and eighteenth centuries as a result of the developments of agrarian production-i.e. the introduction of autumn rye, arable fields expansion and population increase. This explains the development and persistence of flooding problems during the studied period, as well as the sense of urgency in the discourse of at least certain individuals in the court protocol from 1787.

The court cases of the late eighteenth century were largely a manifestation of these changes, although the people involved at the time did not see the agrarian development or changing land use as a principal cause. Instead, the solutions promoted by the groups and individuals active in the court were colored by the legal principles of the time, such as the principle of natural flow and the legal institution of kungsådra (see above). Such principles were constructed in a time when problematic water flows presumably were commonly caused by the damming of waterways through mills, especially when these were relatively new phenomena, although they also served other purposes such as fostering fish migration.

Bo Fritzbøger (2009) has shown similar tendencies in his environmental history of the river Skjern in Denmark. Conflicts over water during the seventeenth and eighteenth centuries had predominantly been handled as conflicts between people, due to the character of water law as well as the Lutheran-orthodox world-view, rather than seeking causes in the relationship between humans and nature. It was first when the economic progression of society was hindered by 'harmful waters' that natural phenomena and processes became the object of discussion (Fritzbøger 2009, pp. 87-91).

The inhabitants of Mörlunda were especially insistent that the hill top of Häcklaberget was the principal cause for their problems, something which can also be attributed to the new law of 1764 where natural obstructions were included. The new laws of the eighteenth century dictating that natural obstacles could be removed were most likely related to the developments of agriculture. Nature stood in the way of agricultural development and should also be governed by humans to fulfil the principle of natural flow (Jakobsson 1996b, pp. 90-91). While the floods of the late eighteenth century persisted in causing damage to the agrarian production in the studied area, the change in attitude can thus also be tied to a wish for future agrarian expansion on the floodplain.

\section{Variations in weather and the limitations of memory}

The disconnection between agrarian development and the inhabitants' interpretation of flooding problems points towards a human understanding of the environment based mostly in immediate contemporaneity. While some historical references to previous floods are made in the court cases, the major and frequent floods between 1695 and 1708 are not 
mentioned (see below). Instead, the inhabitants of Mörlunda in the protocol of 1787 state that "the abundance of water before 1730 was more rarely seen (Handbörds häradsrätt 1787: 732)."

In the court records and proceedings from the late eighteenth century, flooding was generally discussed in relation to human alterations and management and not as a naturally occurring phenomenon caused by variations in weather. However, a few witness testaments reveal that not the least the lay farmers of the area were clearly aware of these variations:

On further inquiry as to whether the witness had noticed that the spring flood now lasts longer than in his childhood, he answered that this is related to the proportion of snow and ice that spring time is turned into water (author's translation, witness testimony from Erik Stensson, 64 years old from Hanåsa (Högsby) and farmer under the estate of Berga, Handbörds Häradsrätt 1787: 792-93).

There is no reason to believe that Erik Stensson drew the wrong conclusions in principle and a more detailed study of the flooding record of the area further supports this picture. The parish records - in combination with the court records-from Högsby, Mörlunda and Målilla can be used to construct a continual series of flooding events in this area from 1694 to 1800 . A few records exist from the late sixteenth and early seventeenth centuries, but due to discontinuity with the rest of the period these are not included in the analysis. Previously, Dag Retsö (2015) has produced a series of flood frequencies for the period 1400-1800 using documentary source material on a national level in Sweden, separating spring and rainfall floods, and also sorting these according to their magnitude on a scale from 1 to 3 . This scale compares the floods according to their regional/supra-regional effects, duration and damage. These are difficult factors to estimate, as the source material used is diverse and produced under differing circumstances with varying terminology, which makes a certain degree of interpretation necessary (Retsö 2015, p. 1309).

A similar methodology has been used in this paper, although adapted to fit a localrather than national-scale as well as a shorter continuum of flood records. As this study only concerns one river, the three-graded scale here is directly relating to the damage caused by the floods rather than their regional magnitude. The character of the source material also differs somewhat between the start and end of the studied period. For the period up until 1750, two parish records of spectacular events are used (Högsby 1704-1729, Mörlunda 1694-1750), which often give vivid and sometimes rather extensive descriptions of the floods and their consequences. In the period after 1750, only one such series of records exist (Målilla, 1743-1800), and the main source material used consists of notes in the statistical tables of Tabellverket. ${ }^{15}$ These notes are much shorter, written with a "drier" tone. These factors must thus be taken into consideration, but the overlapping of the statistical tables with at least one event record rectifies this problem to a certain degree. Both materials were written down by parish priests in accordance with the church law from 1686 and later decrees from the eighteenth century. While earlier records were mostly governed by interest in spectacular events, from 1774 and onwards the notes in the statistical table are more aligned towards agricultural yields and natural phenomenon (Ingesson 2017).

\footnotetext{
15 The records from Tabellverket contains yearly notes on weather and agricultural yields (as well as prices), but weather notes are found rather sporadically where some parishes have continual notes each year and others only for a few years. The results presented here are the result of combination of records from the connected parishes of Högsby, Mörlunda, Målilla, Tveta and Fliseryd, all situated in connection to Emån. See corresponding church archives (series GIII) in the reference list.
} 


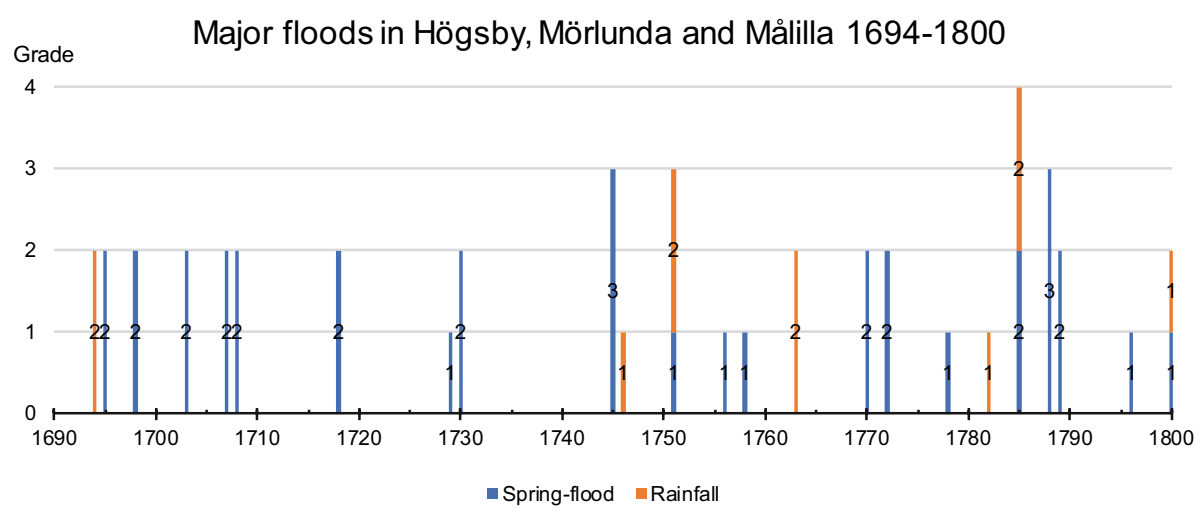

Fig. 5 Individual floods in the parish records of Högsby, Mörlunda, Målilla, Tveta and Fliseryd 1694-1800 and their principal causes. Each bar represents one flood. The floods are graded on a scale from 1 to 3 according to their negative effects on society. $1=$ only minor effects with limited consequences. $2=$ major effects on a large part of the agrarian production. $3=$ Major and widespread effects on large parts of the agrarian production, also including destruction of property and/or human or cattle casualties

As can be seen in Fig. 5 the floods during the turn of the eighteenth century were quite numerous and had rather even but major consequences. Between 1695 and 1708 , five spring floods and one in summer caused by rainfall occurred. These floods often had negative effects on the arable fields and affected waterworks such as mills and weirs, or swept away fences. Between 1708 and 1745, the major floods recurred with 10-14 years in between, peaking in 1745 with a dramatic event causing major damages as well as human casualties. After the event of 1745 , pluvial summer floods became a slightly growing problem as compared to the earlier half of the eighteenth century. In 1763, the priests in Mörlunda and Tveta note that the largest summer flood in living memory occurred with drastic consequences for both meadows and arable fields. After 1745, no major spring flood occurred until 1770, with only three minor events in the 1750s. One of the most dramatic spring floods occurred after a severe winter in 1788, one year after the court of 1787 studied in the previous section, causing major damage to fields and properties.

This pattern can be related to other studies. Dag Retsö shows that the 1700s and 1720s were decades with large clusters of floods in Sweden, and in 1701-1710 show a comparative peak in floods with disastrous consequences. Apart from a relative peak in disastrous floods in the decade 1771-1780, the magnitude of the floods decrease during the course of the eighteenth century (Retsö 2015). This might explain the limited frequency of major floods observed at the end of the eighteenth century in the lower reaches of the river Emån. The gap in major spring flood recurrence between 1745 and 1770 is to some extent also reflected in Retsö's results, especially a period without any spring floods 1761-1770. Retsö ties the peak in flood recurrence and magnitude especially during the early eighteenth century to the peaking of the Little Ice Age, which has been tied to flood frequencies in other contexts as well (Retsö 2015, p. 1312).

It seems clear that the years preceding the court cases of the late eighteenth century saw a gap in major spring flood recurrence. This meant that the spring flood of 1770 was a rather sudden event that may have appeared unlikely in its contemporary context. While a slight decrease in flood recurrence, as well as consequences, is apparent during the course of the eighteenth century, this decrease is most likely tied to actual diminishing flood 
magnitudes, further supported by the evidence presented by Retsö (2015). The increased frequency of low magnitude floods after 1750 can be tied to the expanding source material, as it was mostly major events that entered the parish notes of earlier years. The late seventeenth and early eighteenth century stands out as a period dominated by high spring flood recurrence both locally and nationally. In relation to the decreasing flood frequency after this peak, it can be presumed that floods in categories 2 and 3 represent floods of either equal or perhaps even smaller size to the ones of the peaking period.

In relation to the flood record, the statement in 1787 that flooding had increased in comparison to the period before 1730 was obviously flawed. Most likely, this is related to the fact that the people active in the court case in 1787 were not alive during the earlier flood-intensive period. Indeed, the oldest witness (74 years old from Högsby) interrogated in the court protocol was born in 1713. A recent study of flood memories in the Vltava basin of central Europe emphasised the continuous degeneration of memories of disasters after one or two generations, especially when living memory (in the form of living people remembering the event) is turned into distant memory (Fanta et al. 2019). Similar conclusions can be drawn from the present study, where the people involved at the time were more concerned with events in living memory, such as the building and relocation of mill dams, blasting projects and recent increases in flood frequency. Usually, such events could be effectively handled in the context of the laws regulating the management of water. However, the overall underlying cause being changes and expansions of land use, those laws were unfit to handle environmental problems in the on-going progression of agriculture (c.f. Fritzbøger 2009, pp. 87-91). While the decree in 1764 presented possibilities of changing the natural conditions, the discussion was still centred on short-term perspectives with limited historical reflections. The development of land use was tightly tied to contemporary needs, and the reclamation of arable land a slow process to which lasting and emotional memories could not be easily tied. Shifting to autumn rye cultivation during the turn of the eighteenth century was an important shift, but in 1787 that change was already a distant inactive memory and the practice it entailed a structural part of everyday life.

\section{Conclusions}

This paper has analysed the development of flood-related problems in two parishes in southeastern Sweden in relation to the historical development of agriculture. It seems clear that the acceleration of flood-related agricultural problems started in the late seventeenth century through a combination of the introduction of autumn rye in floodplain contexts and an on-going expansion of arable fields. Autumn rye introduced a prolonged period of flood-risk exposure for the arable crops, the problems of which are clear when analysing the written source material. The arable field expansion in combination with larger processes of agrarian development continued throughout the eighteenth century, gradually increasing the dependence on floodplain meadows when dry meadows were reclaimed as arable. The amount of arable fields on the floodplain also increased during this period, contributing to a larger area of crops within the floodplain boundary.

Floods during this period seem to have been generally interpreted within existing systems of flood and river management, whilethe development of water law in the eighteenth century reflected changing relations to flowing water. New laws on a national level were introduced as an answer to the requirements of the nation's agricultural development. In the late eighteenth century, a gap in major spring floods in the studied area contributed to the 
interpretation that such floods were caused by human constructions or natural obstruction in the river channel when large spring floods reappeared after 1770. The frequent floods at the turn of the eighteenth century were more or less forgotten at this time. Larger economic processes affecting the sensitivity of society to floods seem to have passed more or less unnoticed by the local inhabitants, who-as manifested in the court protocols-focused their discussion on recent human interventions in the water's flow as well as unfavourable natural elements in the river, such as Häcklaberget.

The contemporaneity of the local flooding discourse can be connected to the importance of living memories in structuring an understanding of environmental disasters (Fanta et al. 2019), but also to the non-existing option of turning against the tide of larger developments in society. Ongoing and past processes of land use change at the time served to sustain the reproduction of everyday life, and continued to manifest themselves physically in the landscape. While flooding constituted a short-term threat to this reproduction, in the long term it is obvious that society managed to survive in the area. Although long-term changes in land use increased the sensitivity to flooding, there was thus no reason to question the system that, despite this, continued to sustain society.

Returning to the "water system" perspective (Tvedt and Coopey 2010), the interconnections in this paper between physical geography, economy and concepts/institutions are clear. The physical geography of the river Emån have produced certain conditions to which all human activity in the area must adapt, either locally through land use or on larger institutional and economic levels. The introduction of autumn rye, for example, could be viewed as an attempt to negotiate this arena of local climate and larger societal developments which produced certain conflicts with the river itself-i.e. ruined harvests through floods. In turn, those conflicts in combination with increased pressure on local resources through arable field expansion and population increase would eventually lead to regulation and draining of the river and its floodplain. Such developments required-and to some degree "determined"- the renewed institutional frameworks of water management that were later introduced during the course of the nineteenth century (e.g. Fryksén 1973; Jakobsson 2010).

This paper has revealed the tension between local agrarian processes of change and earlier water management practices, and also how it is often impossible for the people living through such changes to observe and critically engage a seemingly inevitable development. Such a view on human-river relations would be difficult to capture without a close inspection of the local empirical material and engaging in an analysis of both agrarian-economic and conceptual dimensions. There is still a high potential in similar studies of other geographic areas and time periods, which combined with the general call for comparative research (Evenden 2018) would enhance our understanding of human-river relations through time.

Acknowledgements The author would like to thank Anders Wästfelt, Johan Berg and Ådel Franzén for productive comments and discussions during the writing process. Lars-Ove Westerberg has also been an invaluable source for discussions of the physical geography of the river Emån. An early version of the paper was presented at the seventeenth International Conference of Historical Geographers in Warsaw 2018, which was made possible through a grant from Lagrelius Fund for Geographical Research. Funding for field work in connection to the article was provided by a grant from The Royal Gustavus Adolphus Academy for Swedish Folk Culture.

Funding Open access funding provided by Stockholm University. 


\section{Compliance with ethical standards}

Conflict of interest The author declares that he has no conflict of interest.

Open Access This article is licensed under a Creative Commons Attribution 4.0 International License, which permits use, sharing, adaptation, distribution and reproduction in any medium or format, as long as you give appropriate credit to the original author(s) and the source, provide a link to the Creative Commons licence, and indicate if changes were made. The images or other third party material in this article are included in the article's Creative Commons licence, unless indicated otherwise in a credit line to the material. If material is not included in the article's Creative Commons licence and your intended use is not permitted by statutory regulation or exceeds the permitted use, you will need to obtain permission directly from the copyright holder. To view a copy of this licence, visit http://creativecommons.org/licenses/by/4.0/.

\section{References}

\section{Digital sources}

Palm LA (2014). Sockenvis jordbruksstatistik för 1810. Svensk nationell datatjänst. Version 1.0. Göteborgs Universitet, Historiska Institutionen. https://doi.org/https://doi.org/10.5878/002159

Sveriges Geologiska Undersökning, SGU. https://www.sgu.se/

SHiPS, Swedish Historical Population Statistics. http://ships.ddb.umu.se/

SMHI Vattenwebb, numbers for station 1806, Blankaström. http://vattenweb.smhi.se/station/

\section{Archival Sources}

Aspelands häradsrätts arkiv, A I a: 42. 1772. Landsarkivet i Vadstena.

Fliseryd kyrkoarkiv, GIII. Redogörelser för folkmängden. Landsarkivet i Vadstena

Handbörds häradsrätts arkiv, A I a: 55. 1787. Landsarkivet i Vadstena.

Högsby kyrkoarkiv, K I: 1-2. Sockenstämmans protokoll och handlingar. Landsarkivet i Vadstena

Högsby kyrkoarkiv, GIII. Redogörelser för folkmängden. Landsarkivet i Vadstena

Kammarkollegiet, 522 Ämnessamlingar, 14:14, Kalmar och Öland. Handlingar från kvarnkommissionen 1697.

Länsstyrelsen i Kalmar län. Landskansliets arkiv. EI:1. Landsarkivet i Vadstena.

Mörlunda kyrkoarkiv, C:1. Födelse- och dopböcker. Landsarkivet i Vadstena.

Mörlunda kyrkoarkiv, GIII. Redogörelser för folkmängden. Landsarkivet i Vadstena

Målilla kyrkoarkiv, C:1-3. Födelse- och dopböcker. Landsarkivet i Vadstena.

Målilla kyrkoarkiv, GIII. Redogörelser för folkmängden. Landsarkivet i Vadstena

SDHK, Svenskt Diplomatariums Huvudkartotek, Riksarkivet.

Tveta kyrkoarkiv, GIII. Redogörelser för folkmängden. Landsarkivet i Vadstena

\section{Historical Maps}

LSA G1 (1642). Emån

LSA g4:90-91 (1646). Geometrisk avmätning, Högsholm.

LMA 08-hby-7 (1706). Skattläggning, tegskifte, Virstad.

LSA G41-43:1 (1692). Avmätning, Skurebo.

LSA G70-18:1 (1692). Avmätning, Gässlingsäng.

LSA G41-46:1 (1695). Avmätning, Staby.

LSA G41-7:1 (1695). Avmätning, Berga.

LSA G70-30:1 (1696). Avmätning, Lundtorp

LSA G70-39:1 (1696). Avmätning, Ryningsnäs.

LSA G41-44:1 (1705). Avmätning, Släthult. 
LSA G41-37:1 (1706). Mjösebo, avmätning.

LSA G41-7:2 (1720). Laga delning, Bergboäng

LSA G19-10:1 (1724). Avmätning, Stora Klobo.

LSA G41-51:2 (1771). Avmätning, Virstad.

LSA G65-1:1 (1778). Avvägning, Emån.

LMA 08-hby-371 (1851). Delning, torpet Smed-Dumpan.

SGU Ab. Hvetlanda.III.Ö.37 (1885). Geologiskt kartblad.

\section{Literature}

Andréasson L, Carlsson U (1973) Emån En hydrologisk och regleringsteknisk studie. Examensarbete, Chalmers University, Gothenburg

Aronsson M (1979) Slåtter- och betesmark i det äldre odlingslandskapet. In: Odlingslandskap och livsform. Odlingslandskap och livsform 1979

Axelsson R, Rahmqvist S (1999) Det medeltida Sverige Bd 4 Småland, 4 Aspeland, Sevede, Tuna län. Vitterhets-, historie- och antikvitetsakad, Stockholm

Beronius Jörpeland L, Qviström L, Ågren H (2013) Kvarnar och kvarnlandskap i Rasbo under tidigmodern tid: arkeologisk undersökning av en kvarnholme i Lejstaån: Uppland, Rasbo socken, Lejsta 7:1 och Hov 1:7, fornlämning 670: arkeologisk undersökning. Upplandsmuseet, Uppsala

Blackbourn D (2007) The conquest of nature: water, landscape and the making of modern Germany. Norton, New York

Brunius J, Ferm O (1990) Det medeltida Sverige Bd 4 Småland, 2 Handbörd. Vitterhets-, historie- och antikvitetsakad, Stockholm Stranda

Bylund E (1996) Lule älvdal i ett kulturgeografiskt perspektiv. In: Baudou E (ed) Att leva vid älven. Åtta forskare om människor och resurser i Lule älvdal, Cewe-förl, Bjästa, pp 183-222

Campbell Å (1982) Från vildmark till bygd: en etnologisk undersökning av nybyggarkulturen i Lappland före industrialismens genombrott. Två förläggare, Umeå

Charlton R (2008) Fundamentals of fluvial geomorphology. Routledge, London

Craelius MG (1986) Försök till ett landskaps beskrivning uti en berättelse om Tunaläns Sefwede och Asbolands häraders fögderi uti Calmar höfdingedöme. J Gunnar Söderbergs förlag, Vimmerby

Dedering C (2001) Kulturhistoria ur dimma: Emåns avrinningsområde. Länsstyr Kalmar län, Kalmar

Donahue B (1989) "Dammed at both ends and cursed in the middle: the "flowage" of the concord river, 1798-1862. Environ Rev 13:44-67

Edvinsson RB (2015) Recalculating Swedish pre-census demographic data: was there acceleration in early modern population growth? Cliometrica 9:167-191. https://doi.org/10.1007/s1169 8-014-0112-z

Ek SB (1962) Väderkvarnar och vattenmöllor: en etnologisk studie i kvarnarnas historia. Stockholm

Emanuelsson U, Möller J (1990) Flooding in scania: a method to overcome the deficiency of nutrients in agriculture during the nineteenth century. Agric Hist Rev 38:127-148

Evenden M (2018) Beyond the organic machine? new approaches in river historiography. Enviro Hist Durh N C 23:698-720. https://doi.org/10.1093/envhis/emy054

Fanta V, Śálek M, Sklenicka P (2019) How long do floods throughout the millennium remain in the collective memory? Nat Commun. https://doi.org/10.1038/s41467-019-09102-3

Fritzbøger B (2009)Vandets veje: Skjern Ås miljøhistorie gennem 350 år Gyldendal Kbh

Fryksén A (1973) Debatten om vattenavtappningar och Hornborgasjöns sänkning - ett led i svensk jordbrukspolitik fram till mitten av 1800-talet. [Lund]

Gadd C-J (2011) The agricultural revolution in Sweden 1700-1870. In: Myrdal J, Morell M (eds) The agrarian history of Sweden: from 4000 BC to AD 2000. Nordic Academic Press, Lund, pp 157-160

Granlund J (1969) Högsby socken och dess byar, näringsliv samt sed och tro. In: Eriksson H, Franzén O (eds) Högsbyboken : Högsby, Långemåla och Fågelfors bygd och liv. D. 1. Högsby kommun, Högsby, pp 63-562

Håkansson A (1997) Dränering, sjösänkning och ängsvattning. In: Larsson BMP, Morell M, Myrdal J (eds) Agrarhistoria. LT, Stockholm, pp 92-102

Höglin S (2001) Landskapets agrara avtryck: agrar landskapsanalys i Kalmar län. Kalmar, Kalmar läns museum

Holmbäck ̊̊ (1914) Kvarnkommissionerna : enligt kungl. breven den 13 april 1697. Stockholm

Ingesson S (2017) Historiska anteckningar i kyrkoarkiven : en ofta förbisedd källa. In: Riksarkivets årsbok. Riksarkivets årsbok 
Jakobsson E (1996a) Industrialisering av älvar: studier kring svensk vattenkraftutbyggnad 1900-1918. Historiska institutionen, Univ., Göteborg

Jakobsson E (1996b) "Wårt till så betydlig del af watten genomskurna land" - svensk vattenrättshistoria i ett internationellt perspektiv. In: Linnér B-O, Svidén J (eds) Miljöhistoria på väg: artiklar presenterade vid Miljöhistoriskt möte 1995. Tema Vatten i natur och samhälle, University Linköping

Jakobsson E (2002) Industrialization of rivers: a water system approach to hydropower development. Know Techn Pol 14:41-56. https://doi.org/10.1007/s12130-002-1014-0

Jakobsson E (2010) The history of flowing water policy in Sweden: from natural flow to industrialized rivers. In: Tvedt $\mathrm{T}$, Coopey $\mathrm{R}$ (eds) Rivers and society: from early civilizations to modern times. I. B, Tauris, London, pp 424-439

Jakobsson E (2013) Ditching from a water system perspective. Draining the Swedish water landscape 1200-1900. Water Hist 5:349-367. https://doi.org/10.1007/s12685-013-0089-8

Lagerstedt T (1953) Jordbruket i Småland under 1500- och 1600-talen. In: Schiller H (ed) Småland. AB Svensk Litteratur, Stockholm, pp 162-173

Lennqvist J (2007) Våtmarkshistoria: Hjälmarens och Kvismarens stränder under 1800- och 1900-talen. Universitetsbiblioteket, Örebro

Mathar W, Kleinebecker T, Hölzel N, Collins B (2015) Environmental variation as a key process of coexistence in flood-meadows. J Veg Sci 26:480-491. https://doi.org/10.1111/jvs.12254

Mauch C (2009) Introduction. In: Mauch C, Pfister C (eds) Natural disasters, cultural responses: case studies toward a global environmental history. Lexington Books, Lanham, pp 1-16

Mauch C, Zeller T (2008) Rivers in History and Historiography. In: Mauch C, Zeller T (eds) Rivers in history: perspectives on waterways in Europe and North America. University of Pittsburgh Press, Pittsburgh, pp 1-10

Mels T (2014) Primitive Accumulation and the Production of Abstract Space: Nineteenth-century Mire Reclamation on Gotland. Antipode 46:1113-1133. https://doi.org/10.1111/anti.12083

Morgan JE 2015 Flooding in early modern England: cultures of coping in Gloucestershire and Lincolnshire University of Warwick Phd

MSB 2014 Översvämningskartering utmed Emån Sträckan från sjön Grumlan till Östersjön samt biflödet Silverån från Silverdalen Myndigheten för samhällsskydd och beredskap

Myrdal J (2011) Farming and feudalism: 1000-1700. In: The agrarian history of Sweden: from 4000 BC to AD 2000 Lund: Nordic Academic Press

S-O Olsson 2003 Märgel och småvatten i Halland: Vattenavtappningar på 1800-talet och våtmarksskapande på 2000-talet. In: Mårald E, Nordlund C (eds) Värna, Vårda, Värdera. Miljöhistoriska aspekter och aspekter på miljöhistoria. Landskapet som Arena, Umeå, pp 19-30

Palm LA (2000) Folkmängden i Sveriges socknar och kommuner 1571-1997: med särskild hänsyn till perioden 1571-1751. L A Palm, Göteborg

Palm LA (2005) Avkastningsskillnader - roten till de olika odlingssystemen. In: Bruka, odla, hävda : odlingssystem och uthålligt jordbruk under 400 år. Kungl. Skogs- och Lantbruksakademien, Stockholm

Palm LA (2016) Sweden's 17th century-a period of expansion or stagnation?

Retsö D (2015) Documentary evidence of historical floods and extreme rainfall events in Sweden 14001800. Hydrol Earth Syst Sci 19:1307-1323. https://doi.org/10.5194/hess-19-1307-2015

Runefelt L (2008) Svensk mosskultur: odling, torvanvändning och landskapets förändring 1750-2000. Kungl. skogs- och lantbruksakademien, Stockholm

Runefelt L (2010) Svensk mosskultur som ett överhetsprojekt före, 1886. In: Runefelt L (ed) Svensk Mosskultur Odling, torvanvändning och landskapets förändring 1750-2000. Eskilstuna, Kungl. Skogs- och Lantbruksakademien, pp 27-52

Schönach P (2017) River histories: a thematic review. Water Hist 9:233-257. https://doi.org/10.1007/ s12685-016-0188-4

Siöstedt C (1994) Slåttermaderna - förbisedda i forskningen om det västgötska kulturlandskapet. In: Berggren G, Boqvist A, Svensson A, Östmark B (eds) Mylla mule människa: det västgötska kulturlandskapet, några brottstycken. Västergötlands fornminnesförening, Skara, pp 81-90

Strandin Pers A (2012) Mark i marginalen: drivkrafter, pionjärer och myrodlingslandskap. Stockholms universitet, Stockholm, Kulturgeografiska institutionen

Strömberg LG (2018) Vattenbruk i Västergötland. In: Lokrantz A (ed) Speglingar av vatten. Västergötlands fornminnesförening, Vårgårda, pp 117-126

Tärnfors M (1979) Historik över Fliseryds socken. Mönsterås kommun, Mönsterås

Tockner K, Bunn SE, Gordon C et al (2008) Flood plains: critically threatened ecosystems. In: Polunin NVC (ed) Aquatic Ecosystems. Cambridge University Press, Cambridge, pp 45-62 
Tuvesson M (2010) Vallodlingens betydelse inom mosskulturen. In: Runefelt L (ed) Svensk mosskultur: odling, torvanvändning och landskapets förändring 1750-2000. Kungl. Skogs- och Lantbruksakademien, Kristianstad

Tvedt T, Coopey R (2010) A "Water Systems" Perspective on History. Rivers and society : from early civilizations to modern times. I. B. Tauris, London, pp 3-26

Vestbö-Franzén A (2005) Tresäde i skogsbygd: förändringar i odlingssystem i nordöstra Småland mellan 1550 och 1750. In: Bruka, odla, hävda: odlingssystem och uthålligt jordbruk under 400 år. Kungl. Skogs- och Lantbruksakademien, Stockholm

Vestbö-Franzén Å (2004) Råg och rön: om mat, människor och landskapsförändringar i norra Småland ca 1550-1700. Jönköpings läns museum, Jönköping

Waldén B (1940) Den stora sjösänkningen: minnesskrift med anledning av Hjälmarens och Kvismarens sjösänkningsbolags 75-årsjubileum. Utg, Örebro

Wedblad D (1894) Hydrografiska undersökningar inom Emåns flodområde. Kalmar läns södra kongl hushållnings-sällskaps periodiska skrift Ny följd 22:155-171

Westman KG (1920) Aktsamling till kungsådreinstitutets historia. Uppsala

Wiking-Faria P (2009) Freden, friköpen och järnplogarna: drivkrafter och förändringsprocesser under den agrara revolutionen i Halland 1700-1900. Institutionen för historiska studier, Göteborgs universitet, Göteborg

Publisher's Note Springer Nature remains neutral with regard to jurisdictional claims in published maps and institutional affiliations.

Oscar Jacobsson is a PhD student at the department of Human Geography, Stockholm University. He previously holds an M.A in Historical Archaeology from Lund University and a B.A. in geography from Dalarna University. His $\mathrm{PhD}$ project analyses historical human/environment relations in the floodplain contexts of the two rivers of Ätran and Emån in southern Sweden from the early middle ages into the early 20 th century. 